\title{
Integrating the traditional and the modern conflict management strategies in Nigeria
}

\section{Akeem Ayofe Akinwale}

\begin{abstract}
The study examines the modalities for integrating traditional and modern conflict management strategies in Nigeria using an analysis of relevant documents as well as Black's Social Control Theory and Thomas-Kilmann's Model of Conflict Management. The successful amalgamation of diverse groups has radically shifted from being a platform for peaceful coexistence to an arena of violent conflicts due to the matrix of social inequality and the state attempts to undermine the power of traditional social control systems. The police and military have been used to suspend several violent conflicts in Nigeria, but they have been unable to build peace despite their coercive power. The social structure
\end{abstract}

* Dr Akeem Ayofe Akinwale is lecturer in the Department of Sociology, Faculty of Social Sciences, at the University of Ibadan, Nigeria. He teaches Cultures and African Social Institutions, among other courses. His areas of research and interest include industrial sociology and development studies. He is an active member of the International Sociological Association (ISA) and the Global Development Network (GDN), a Laureate of the Council for the Development of Social Research in Africa (CODESRIA) and a Fellow of African Regional Sexuality Resources Centre 


\section{Akeem Ayofe Akinwale}

and deep-seated grievances that generate violence have not been addressed and the crowding out of traditional methods of social control from official policies has left room for escalation of violent conflicts. The most disturbing of these conflicts are ethno-religious and resource-control conflicts, which have both resulted in monumental destruction of peoples and properties and exposed different parts of Nigeria to crisis. It is argued that a policy-driven synergy of useful traditional and modern strategies for conflict management will result in lasting peace in Nigeria.

\section{Introduction}

Efficient and effective management of conflicts is fundamental to the development of any society, but the prevailing situations in Nigeria constitute a reversal of this reality. The Nigerian success story of amalgamation of diverse groups in 1914 has radically shifted from a platform for peaceful coexistence to an arena of violence and gradual disintegration. The popular explanations for this unexpected situation include colonialism, corruption and political instability. The matrix of social inequality and the state attempts to undermine the power of traditional social control systems are also potent factors, but there is inadequate research on this subject matter.

The spate of insecurity and threats to lives and properties in Nigeria has reached alarming proportions despite the increasing visibility of the Nigerian state mobile police and military in the management of internal conflicts (The US Department of State 2008; Erinosho 2007; Falola 1998). About 50 episodes of violent conflict, which culminated in the death of over 10000 persons and internal displacement of over 300000 people, were recorded in Nigeria between 1999 and 2003 (International Crisis Group 2009). The recent (28-29 November 2008) violent conflict in Jos (a city in the north-central) resulted in the death of over 380 persons and destruction of properties worth millions of naira (Adinoyi 2009; Balogun 2009; Eya 2009; USAID 2005). Considering the increase of violent conflicts and occasional state failure in the maintenance of peace and order in Nigeria, this study is anchored by the following questions: How has Nigerian society coped with its monumental profile of violent conflict? Why are extant conflict management strategies defective? What are the modalities for 
integrating traditional and modern conflict management strategies in Nigeria? These questions are addressed through content analysis of relevant documents.

This study is situated within the confines of Black's Social Control Theory and Thomas-Kilmann's Model of Conflict Management to provide a robust foundation for the explanation of processes involved in peace-building in Nigeria. Black's theory proposes the conditions that predict the use of one of five forms of social control (self-help, avoidance, negotiation, settlement, and toleration) in the relationship between individuals, groups, and organisations, while ThomasKilmann's model explains strategic intentions that could be organised around the matrix of two factors (assertiveness and cooperativeness), which jointly produce five conflict management styles (avoidance, accommodation, competition, compromise and collaboration) (Volkema and Bergmann 1995; Borg 1992; Black 1990; Thomas 1992). The established complexity of violent conflicts in Nigeria requires a combination of approaches as proposed in this study. The combination is also needed for theoretical and methodological support in the proposed integration of traditional and modern conflict management strategies.

The above perspectives have been used extensively in American academic research, training seminars and development studies; however few studies have linked the intentions measured by the model with actual behaviours (Volkema and Bergmann 1995; Borg 1992). This study includes an attempt to contribute towards further development of the theories through an examination of their applicability to the management of Nigeria's protracted violent conflicts. Black's theory and Thomas-Kilmann's model are contemporary versions of the twodimensional modes of conflict management introduced by Blake and Mouton in 1964 (Volkema and Bergmann 1995).

According to Thomas-Kilmann's model, assertiveness flows from concerns for self-interest, while cooperativeness is driven by concerns for the other party or the relationship (Thomas 1992). This assertion has opened up the stage for a discourse on conflict management strategies in Nigeria where self-interest remains paramount in the country's political economy. As defined by Black (1990:43), conflict management is 'the handling of grievances'. This definition is adopted for this study due to its simplicity and relative applicability. The 


\section{Akeem Ayofe Akinwale}

conditions under which each of Black's conflict management styles is likely to occur differ (Borg 1992).

The above mentioned dichotomy implies that self-help or avoidance may be preferred in some situations, while negotiation or settlement would be required in others, especially if toleration is not possible. In Nigeria, some of these strategies are more likely than others to be used in the context of 'order from above' at the expense of ethnic minorities or the less-privileged groups. The minorities and the less-privileged groups may also resort to alternative strategies in their relationships with the more powerful groups. Individuals and groups that share relatively equal status - like the Nigerian Muslims and Christians - may also adopt a different approach to conflict management. In this regard, existing strategies for the management of Nigeria's violent conflicts can be located within the classifications in Black's theory and Thomas-Kilmann's model.

The USAID's (2005) argument that the Nigerian government's capacities for managing conflicts are weak appears valid because the government has not fully considered the utility of every available strategy for conflict management. When conflicts erupt, the inability of the Nigerian mobile police to manage them usually prompts the Nigerian government to deploy the Nigerian military to the scene of violence where the military are usually mandated to 'shoot on sight.' This situation sometimes leads to serious human rights violations and escalation of violence (Ibeanu 2006). The state's imposition of curfew and use of propaganda to douse public tension are part of the Nigerian government's regular strategies for conflict management in Nigeria. In view of the perceived inability of the Nigerian security forces to safeguard human lives in Nigeria, a considerable number of people in the country have however subscribed to unofficial strategies (vigilante, militias, charms, prayers, communal solidarity, etc) in their attempts to manage Nigeria's violent conflicts.

The emerging strategies in the management of Nigeria's violent conflicts have a strong foundation in African traditional cultures. Contrary to general belief in western paradigms, every African community has capacities for promoting mutual understanding and peaceful coexistence (Lauer 2007). Uncritical 
adoption of Western approaches to conflict management has adversely affected the stability and development of many African societies including Nigeria.

In light of the foregoing, this study focuses on the possibility of integrating both traditional and modern conflict management strategies for peace-building and development in Nigeria. The next sections deal with various issues around the subject mater of this study: factors influencing violent conflicts in Nigeria, official strategies for conflict management in Nigeria, traditional strategies for conflict management in Nigeria, shortcomings in Nigeria's conflict management strategies, integration of traditional and modern strategies for conflict management, and conclusion.

\section{Factors fuelling violent conflicts in Nigeria}

Several studies attribute Nigeria's violent conflicts to the failure of its political elite to accept democratic principles of accountability, equity, justice and the rule of law (Bamgbose 2009; Piiparinen 2007; Abubakar 2006; Adejumobi 2005). Also, most violent conflicts in Nigeria have been traced to contested bases of citizenship rights, greed, predatory rule, autocracy, and unresolved grievances. Prolonged military rule and centralisation of power around Nigeria's remarkable resources aid rent seeking, thereby making it a qualified case for a 'resource curse' thesis as shown in a previous study by Collier and Hoeffler (2005). Different forces such as colonialism, neo-colonialism, dictatorship, alienation, poverty, unemployment, illiteracy, infrastructural decay, ethnic rivalry and religious intolerance constitute the root causes of Nigeria's violent conflicts. These factors transcend the regular causes of violent conflicts in Africa: political history, population, resource insecurity and war economies. There is general agreement among scholars that a monolithic explanation of violent conflicts in Nigeria is inadequate (Guseh and Oritsejafor 2007; Ibeanu 2006; Meagher 2004; Falola 1998). The merger of ethnicity and religion has played out with involvement of southerners and northerners in violent conflicts, which cannot be divorced from the political economy of contemporary Nigeria. The holistic causative factors of violent conflict are worthy of recognition in the process of peace-building and 


\section{Akeem Ayofe Akinwale}

its sustainability. Instances of religion-driven violent conflict were described by Falola (1998:2-3) as shown in the following passage:

Since the mid-seventies, politicians have urged their followers to vote along religious lines - Muslims are told to vote for Muslims, and Christians for Christians. In 1978, the National Party of Nigeria (NPN) told its followers in one of its strong Islamic northern constituencies that the two-fingered V-for-victory sign of the Unity Party of Nigeria (UPN) was a covert symbol of polytheism, an idea counter to fundamental Islamic doctrine. The NPN adopted one raised finger as their symbol, turning the universal (and universally secular) V sign into a religious issue ... The gubernatorial elections in Lagos and Kaduna were deeply affected by religious issue, and the primary process for the 1993 election of a civilian president was complicated by conflicts between Muslim and Christian candidates. Many analysts date the beginning of Nigeria's religious crisis to 1978 (excluding the jihad of 1804)... two religious issues related to whether Nigeria would become a secular state or subscribe to al-Shari'a, the Islamic code of laws, disrupted the constitutional making process... Other religious inspired controversies during the 1970s included the rejection of the recitation of the national anthem and pledge by the Jehovah's Witnesses, ... and the calls by Christian leaders for state-supported pilgrimage to Jerusalem (Muslims were already being sponsored in pilgrimages to Mecca) ... In 1980, the Maitasine crisis claimed thousands of lives (the government conservatively estimated the death toll at just over four thousand) and caused millions of naira in property damage. On the last day of October 1982, eight large churches were burned in the prominent city of Kano ... A major riot in Kaduna the same year claimed at least four hundred lives. In 1984, violence sparked by Muslims in Yola and Jimeta killed approximately seven hundred people (including policemen) and left nearly six thousand people homeless. The neighbouring town of Gombe was also besieged, resulting in the death of more than one hundred people ... In March 1987, Christians in Kafanchan wantonly destroyed the property of local Muslims. Within three days, every one of the hundred churches in Zaria was burned and many Christians had been slaughtered. 
Besides religion, poverty has become a major root cause of Nigeria's violent conflicts given the emerging flows from the economy of violence in the country. In different areas of Nigeria, the unemployed and underemployed youths have embarked on a range of violent activities in search for livelihoods. This situation has produced heroes in the context of political thuggery, assassination, militancy, and ethnic massacre. Some relatively impoverished youth have gravitated into religious fundamentalism with networks stretching across Africa and Saudi Arabia in the case of Islam, and to England and the United States in the case of Pentecostal Christianity (Meagher 2004; Falola 1998). The emerging disorder from communal violence can be understood in this context, which closely ties with the rise in corruption.

The Nigerian government's reactions, including the implementation of neoliberal policies, have attenuated the human capacities for development, thereby building the socio-psychological bases for violence. In the context of the structural adjustment programme and its concomitant trade liberalisation which resulted in dumping of foreign goods in the Nigerian markets, several thousands of local entrepreneurs abandoned their primary occupations following their inability to cover production costs. A crop of youth, who were rendered underemployed by the adverse effects of neoliberal reforms on their productive activities in Aba metamorphosed into the Bakassi Boys vigilante group in 1998; and some politicians hijacked the group in 2000 in their struggle against the Federal government.

The Bakassi Boys were involved in an ethnic riot in which 300 northern Nigerian migrants were slaughtered and in the abduction and assassination of political opponents prior to the 2003 elections (Meagher 2007). Their increasingly violent activities made them the subject of a Human Rights Watch Report in 2002. Other organisations including the Hisha in the north and the Oodua People's Congress (OPC) in the south-west also emerged and fuelled violence in the context of widespread frustrations. These militia groups do not represent a cultural propensity to violent conflicts, but reflect the impact of severe economic stress and state neglect on dynamic local institutions. People are perceived in terms of their ethnicity, religion and social class, and the citizenship question connects with these forces in conflict-prone areas. 


\section{Akeem Ayofe Akinwale}

Also, state promulgations, including the Petroleum Act of 1969 and the Land Use Decree of 1978, favoured the Nigerian government and multinational companies in the country and resulted in the restriction of communities' access to land. This situation and the chronic deprivation associated with it contribute to the rising spate of violence in Nigeria. Local elites in the oil-producing communities have reacted violently against the Nigerian government and oil companies through social movements and the use of ethnic-oriented militia tactics. Guseh and Oritsejafor (2007:140) explain the foundation of Nigeria's violent conflicts as follows:

The country has experienced numerous military coups and counter coups and has survived a secessionist civil war. The attainment of political independence does not seem to have transformed the state because the indigenous elites that replaced the colonial administrators have failed to implement policies to move the country forward politically and economically. The indigenous elites inherited a state that was not designed to cater to the needs of the Nigerian people; yet these elites were content with the political structures designed by the colonialists.

Collier and Hoeffler (2005:632) mention other factors that fuel the proliferation of violent conflicts in Nigeria:

Case studies as well as cross-country studies suggest that countries with an abundance of natural resources are more prone to violent conflict ... in the Delta region of Nigeria, large-scale organized crime is 'bunkering' (i.e., stealing) oil from pipelines to the scale of around $\$ 1$ billion per year, selling it in East Asia. There is obviously scope for this massive criminal activity to link with the political secessionists of the Delta region. Resources can motivate conflict, especially in the form of secessions. Secessionists not only claim ownership of the resources, they also claim that the national authorities are misusing the money - that it is being embezzled by distant elites. Perhaps the best defense against such secessionist pressures is to make the secessionists look greedy. To achieve this, national governments should probably link resource revenues to some basic social service such as primary education. 
The resource curse thesis can be refuted in light of the models of resourceendowed peaceful countries including Norway, Denmark, Sweden, Canada, Australia, the United States of America and the United Kingdom (Cappelen and Mjøset 2009). Resource-endowed communities need not be prone to violence and underdevelopment. For instance, the relatively peaceful Norwegian society had relied on raw materials export and combined economic growth with an egalitarian distribution of income long before its discovery of petroleum. The logic of the resource curse can be dispelled in this way and a plausible argument can be built around lack of transformational leadership as a major determinant of violent conflict in resource-endowed settings. The question may not be about resource abundance but the quality of leadership in charge of the abundant resources. Kotlyar and Karakowsky (2006) examined the relationship between leadership styles and group conflict and their findings support the assertion that:

... differences in leadership behaviors can trigger different levels of cognitive and affective conflict among group members. Behaviors reflective of the transformational style of leadership demonstrated the greatest capacity to motivate group members to constructively debate ideas. However, in contrast to transactional and external leader behaviors, transformational leadership behaviors also showed a greater capacity for igniting affective conflict among group members (Kotlyar and Karakowsky 2006:377).

\section{Official strategies for conflict management in Nigeria}

The Nigerian government's major official strategies for managing violent conflict include state creation and the use of the Nigerian mobile police, the Nigerian military, curfew, propaganda, judicial panel, compensations and punishment. These official strategies have however not yielded adequate results since the 1960s. Nigeria was originally administered as an amalgam of two protectorates before the establishment of new structures such as regions and geo-political zones and states (12 states in May 1967, 19 states in February 1976, 21 states in September 1987, 30 states in 1991 and 36 states in 1996). The outcome of states creation has been summarised by Otite (2000:vii) as follows: 


\section{Akeem Ayofe Akinwale}

These new developments, which were responses to ethnic-sectional demands for new identities or consolidations of old ones, also created new bases for contested territorial and other claims, as well as competition for access or succession to high political and other offices. They were also responses to protests against perceived sectional marginalisation in respect of participation in, and the dividends derived from, the political and economic development of Nigeria under democratic process.

The Nigerian mobile police and the Nigerian military have been used to suspend many cases of conflicts in Nigeria. They have succeeded in restoring order in most cases of violent conflicts, but their intervention usually gets to the violence scene after colossal wastage of human lives and valuable properties. In view of their late responses, the coercive power of the state has been unable to stop preventable violence in Nigeria. Scholars (Thomas and Pondy 1977) have shown that time lag would affect the effectiveness of conflict management activities. Some documented evidence of the failure of the Nigerian mobile police and the Nigerian military in their endeavours to prevent violent conflicts and restore social order are summarised here. In May 1996, eight people lost their lives when the police clashed with a group of Muslim students. The following month, Muslim students at the Kaduna Polytechnic Institute clashed with the police over the hosting of a beauty contest, which they claimed debased Islam. The school had to be closed down to prevent a prolonged escalation of the conflict. Chances that the government could end religious violence with violence of its own became minimal when the federal government itself evidenced a bias for Islam by secretly joining the Organisation of the Islamic Conference in January 1986. The Christian reaction frightened the military government, and a government effort to defuse tension by means of the National Advisory Council on Religious Affairs was abortive. After 1986, religious violence occurred often and without notice, with most outbreaks ending in large-scale destruction and the activation of the army and police to quell riots and protests. In 1990, a group of civiliansupported southern Christian military officers decided to forcibly take over the government, claiming it was controlled by northern Muslims convinced of their 'birthright to dominate till eternity the political and economic privileges 
of this great country'. In a radio address, the plotters of the coup announced the excision of five Islamic states - Kano, Borno, Katsina, Bauch and Sokoto - from the federation. They were unsuccessful, but it was widely speculated that had they achieved their goal, another civil war would have been unavoidable (Falola 1998:4-5).

Furthermore, the Nigerian mobile police forcefully dispersed a large crowd of Muslims at the National Theatre in Lagos in an attempt to avert a religious riot in the 1980s. After the death of six students in 1978 in a clash between Muslim and Christian students of the Ahmadu Bello University, Zaria, the Nigerian military was deployed to quell the crisis. The character of the Nigerian government as it is represented by the Nigerian mobile police and the Nigerian military reflects the assertiveness clause in Thomas-Kilmann's model. This character can however be expected, given the finding of researchers (Volkema and Bergmann 1995:5) that 'preferences for assertiveness are reflected in both strategic and tactical use of behaviours, whereas cooperativeness is associated with last-choice behaviours'. Nigeria is not the only country with a relatively autocratic government. A recent study by Ma (2007) showed that compromise and avoidance are the most preferred methods of conflict management in China, while accommodation and competition lead to more satisfaction during business negotiation. This finding shows that China also has a relatively autocratic government due to her traditional history of a unitary state under the control of a single party. The Chinese polity embodies an autocracy in the context of democratic communism, hence the co-existence between China's authoritarian national government and democratic governance in villages.

Following the death of over 380 people and destruction of property worth millions of naira in a recent (28-29 November 2008) case of violence in Jos, curfew was imposed on four districts of the city and the Nigerian soldiers were permitted to 'shoot on sight' in order to prevent escalation of violence (Balogun 2009). Flight schedules for Jos were cancelled and roads to the north were blocked. The state security agents subsequently arrested 26 suspected mercenaries with weapons, including 22 double barrel guns, eight cutlasses, army boots, tear gas, charms, and army uniforms (Adinoyi 2009). The suspects were referred to the state Criminal Investigation Department (CID) in Jos for further investigation. 


\section{Akeem Ayofe Akinwale}

In view of the failure of the state governor to embark on a timely necessary action, the Federal Government of Nigeria (FGN) set up a judicial panel chaired by Emmanuel Abisoye to investigate the Jos violence. The FGN panel was not constituted until several weeks after the outbreak of the conflict. However, the Plateau State Governor has challenged the FGN's panel through a court injunction, claiming that the FGN has no jurisdiction in managing the conflict in the state. In reprisal, the Governor established another judicial panel of inquiry chaired by Prince Bola Ajibola (Eya 2009). It can be recalled that the FGN suspended the former Governor of the state and declared a state of emergency in the state during the previous conflicts in Jos in 2001 and 2004 respectively. Presently, the emergence of two judicial panels on the same issue has generated controversies in the country and popular opinions are divided on it.

It is noted that a dominant Islamic organisation expressed dissatisfaction over the state-driven parallel judicial panel of inquiry claiming that it would honour the panel constituted by the FGN. In contrast, some Jos indigenes were said to have planned to disregard the FGN judicial panel due to its perceived bias in favour of the Hausa/Muslim community recalling Emmanuel Abisoye's involvement in the trial and elimination of some indigenes of the state during the case of late Col. Buka Suka Dimka in Nigeria's coup of 1976. The emerging controversy over the way and manner in which the Nigerian government is handling the recent conflict in Jos has set the stage for future conflict in the city. The likely continuity of violence in Jos and elsewhere in Nigeria can be traced to the principle of attribution, which remains attractive to the majority of the population. Attribution implies a process by which blames are shifted among parties to a conflict. This process is a fundamental element of conflict scenarios in Nigeria where shifting of blames has prolonged peace-building efforts. Thomas and Pondy (1977) examined the role of attributed intent within conflict episodes, and found that attributions cause hostility and retaliation between parties to a conflict. In light of attribution, which may affect perception of justice or injustice, individuals tend to perceive themselves as cooperative and reasonable, but attribute competitiveness and unreasonableness to the other party. This situation provides a basis for resurgence of violence and extension of peace-building initiatives in Nigeria. 
Official strategies used in the south-south include concentrated military operations, establishment of commissions, establishment of a new ministry, and an amnesty offer. The Nigerian government established the Niger Delta Development Commission (NDDC) in 2000 to replace the military-driven Oil Mineral Producing Areas Development Commission (OMPADEC). The NDDC was restructured with a comprehensive master plan in 2007 and a new ministry (the Ministry for Niger Delta Affairs) was established in September 2008 for infrastructure development and community empowerment in the region. Violence remains unabated in the Niger Delta despite the above mentioned strategies, thereby confirming Piiparinen's (2007) report on persistence of the root causes of violence in the context of democratic rule with a disconnection between policies and practices.

The prevailing practices in the official strategies for conflict management in Nigeria partly fit Black's theory. Drawing on this theory, it has been argued that:

... the status of nations within the world-system at a particular time is correlated with the primary strategy they use for conflict management and ... the strategy used may affect the nations' subsequent rank (Borg 1992:262).

The above can be connected with Thomas-Kilmann's model, which is organised around two dimensions: assertiveness and cooperativeness. The former is an attempt to satisfy personal concerns, while the latter is an attempt to satisfy collective concerns (Thomas 1992). The two dimensions jointly result in five modes of conflict management: avoidance, accommodation, competition, compromise and collaboration. Both assertiveness and cooperativeness are low in avoidance, which usually result in failure to manage violent conflicts. Cooperation is higher than assertiveness in accommodation, which entails partial management of violent conflicts. Competition in which assertiveness is higher than cooperation involves the indiscriminate use of power by one group against another in the process of conflict management. Both assertiveness and cooperativeness are respectively intermediate and low in compromise and 


\section{Akeem Ayofe Akinwale}

collaboration - which usually yields concessions and desirable outcomes in conflict management.

In light of the above theoretical postulations, the Nigerian government's styles of conflict management include avoidance, accommodation and competition. In contrast, the general traditional strategies for conflict resolution largely conform to the principles of compromise and collaboration as can be seen in the following description.

In the present research, a conceptualization similar to that of Blake and Mouton and Thomas was used to differentiate styles of handling interpersonal conflicts on two basic dimensions: concerns for self and for others...In superior-subordinate communication, subordinates frequently say what is acceptable rather than what they know is true. Therefore, an individual may use a more obliging style with superiors than with a subordinate or peer... Finally, a compromising approach is expected when both parties in a conflict situation have equal power (peers) (Rahim 1983:368-370).

\section{Traditional strategies for conflict management in Nigeria}

Several individuals and groups have embarked on new approaches to deal with unresolved grievances in Nigeria. A south-south social movement led by Isaac Adaka Boro in the 1960s preceded various organisations including the Movement for the Survival of the Ogoni People (MOSOP), which was established in 1990 in response to the Nigerian government's repression of the minorities. The Niger Delta People's Volunteer Force (NDPVF) and the Niger Delta Vigilantes (NDV) were established for the same purpose in 2003 and 2004, respectively. Similar organisations have been established across Nigeria: the Oodua People's Congress in the southwest, Hisha and Arewa People's Congress in the north and Egbesu Boys in the south-south. This situation finds expression in Anderson and Collins' (1998) observation that oppression generates resistance. They suggest that oppression could be resisted effectively through organised actions within a group and coalition building with other groups. Resistance from the grassroots 
has been a fallout of the Nigerian government's failure to amicably resolve extant violent conflicts in the country. The emerging grassroots resistance is driven by traditional institutions.

Traditional institutions are the instruments of social organisation and they provide the foundation for social change (Hussain 2007; Ochoche 2002). The coexistence of traditional and modern social systems has a long history. Traditional methods of social control such as communal solidarity, traditional oaths, rewards, vigilantes, informal settlements, checks and balances, decentralisation, effective communication and good governance remain strong and have been informally used successfully for conflict management in many communities in Nigeria. Nwafo Nwanko and Nzelibe (1990) subscribe to the observation that African kingdoms are reputed for strict observance of the rule of law and the principle of natural justice.

Indeed, the tradition in most African cultures is that reigning monarchs have to go on self-exile, abdicate or commit suicide when found guilty of serious offences against the community. Knowing that power tends to corrupt, and absolute power corrupts absolutely, traditional social institutions have developed necessary in-built mechanisms for preventing power abuse. For instance, the Benin Kingdom displayed dexterity in conflict management through effective and efficient utilisation of its military strength, public administration, and traditional values including loyalty to the system, respect for chieftaincy, and communalism. This is a classical example of traditional modernism. The traditional values were successfully integrated with the then modern institutions of the military and public administration. A previous study by Nwafo Nwanko and Nzelibe (1990:259) provided evidence of the usefulness of some traditional strategies for conflict management in Africa as follows:

Africans strongly believe in the concept of 'communalism.' This is because of their belief that the individual is not alone, but is included under the umbrella of the community. The individual is an amulet system which is instrumental in linking that person to one's environment on the basis of communication principles and conventions ... Conflict management follows similar patterns in Africa. Emphasis is placed on internalised values. 


\section{Akeem Ayofe Akinwale}

Value is placed on honesty, openness, empathy, community solidarity, and individual loyalty to the group, but not at the expense of recognised worth of the individual. Therefore, emphasis is placed on those communication patterns and behaviours which will promote the bond of strong and productive coexistence of groups in the community.

The above submission clearly demonstrates the relevance of several traditional methods of peace-building in Africa. These methods are still valid but have been relegated in official decisions. It is worthy of note that the Nigerian society has over the past several years equipped individuals with necessary peacemaking skills, but the Nigerian government has not fully recognised the usefulness of these skills in its peace-building efforts. Each Nigerian ethnic group has inbuilt support for peace. The Yoruba concept of 'omoluabi', the Hausa concept of 'mutum-kirki' and the Igbo concept of 'ezigbu-nwa' introduce the relevance of ontological capacity for peace-building by cultured individuals. The three concepts signify individuals with exemplary behaviour. Such individuals may not participate in violence irrespective of their anger level.

There is general support for the use of traditional strategies to manage violence in Nigeria as indicated in Afrobarometer's (2002) survey involving 2190 Nigerian men and women selected across 29 states within the six geo-political zones in August 2001. Nigerians prefer informal modes of conflict resolution. Considering preferences in the management of Nigeria's violent conflicts, most respondents offered up to three answers in their own words $(\mathrm{n}=6305)$. Taken together, these indicate that Nigerians are twice as likely to prefer an informal communitybased process rather than an official intervention by the state government or the federal agency (54 versus 26 percent of all responses). At the community level, people are most likely to turn to chiefs, headmen or elders to mediate disputes (17 percent of all responses), especially in the parts of the country where traditional leaders continue to perform customary functions. Thereafter, people request resolution from religious leaders (14 percent) such as a pastor in a Christian church or an imam in an Islamic brotherhood. Interestingly, few people seek help from civic or non-governmental organisations (1 percent). In the absence of organised channels, people commonly resort to self-help, insisting that 'the 
people involved in the conflict' find a solution for themselves ( 8 percent) or they turn to 'family, friends and neighbors' ( 7 percent). In the extreme, they may even enlist the help of vigilante groups ( 2 percent). In practice, Nigerians see little use of government as an agent of conflict resolution. When they mention the central government at all, they call on its coercive agencies - the army and the police (16 percent of all responses) - rather than on its judicial branch (4 percent). Nor do they make use of local courts or local government administration (9 percent), perhaps because they do not expect fair or effective treatment. In keeping with their pride in Nigeria's status as an African superpower, even fewer Nigerians think that international agencies have a role in resolving internal conflicts. Predictably, rural dwellers strongly advocated for community-based solutions, while urban dwellers are more prone to turn to government. Southeasterners put most faith in community organisations ( 62 percent) as compared to Lagosians, one third of whom would seek out an agency of a local, state, or federal government (36 percent). Expectedly, persons who express a religious identity tend to prefer religious leaders to resolve conflicts. More interestingly, persons who define themselves in terms of their region of origin (e.g. Westerner, Easterner) are especially likely to enlist the assistance of a vigilante group.

The survey by Afrobarometer (2002) resonates with Lauer's (2007:288) call for refutation of the notion that ' $\mathrm{t}$ ] he global arena is dominated by the popular conviction that Africans require foreign direction in the socio-economic management of their own societies'. The relevance of Black's theory of social control and Thomas-Kilmann's model of conflict management also plays out in Afrobarometer's (2002) findings, which have several implications for security management, peace-building, and development in Nigeria. The need for a preventive diplomacy and a participatory approach to the management of Nigeria's violent conflicts can be understood in this light.

\section{Integration of traditional and modern strategies for conflict management}

Studies largely indicate that violent conflicts can be managed effectively by the disputants themselves or by third parties (Myerson 2009; Milner 2002; 


\section{Akeem Ayofe Akinwale}

Rahim 2000; Wall and Callister 1995). Recognition of this fact would result in de-escalation of violence if the affected parties are allowed to take appropriate actions. Taking appropriate action is a function of access to an integrated package for conflict management. There is a general capacity for people to manage violence, but distortion of their histories may render them weak and incapable of maintaining peace. The weak institutions, poverty, social inequalities, corruption, civil strife, violent conflicts and civil war are not original conditions but are rooted in specific historical contexts (Osaghae 2007). In view of the above, the realm of social integration is very important in the analysis of conflict management strategies.

An integration of useful complementary values will result in positive transformation in a society. The fundamental values that constitute a society can be connected in defining the elementary conditions under which the society can be regarded to have undergone transformation (Liu 2006:505). Some African countries like Ghana have legislative and judicial decentralisation programmes 'as a framework for integrating aspects of the existing conflict management methods and skills of the national government and the country's ethnic groups' (Fred-Mensah 1999:951).

The modalities for integrating the traditional and the modern conflict management strategies in Nigeria require the following mechanisms: proper identification and elimination of shortcomings in the extant conflict management strategies, resuscitation of useful traditional values that have been jettisoned, and the establishment of a national security policy based on a synergy of the revised traditional and modern strategies. Many traditional institutions with their concomitant beliefs and values have been jettisoned without adequate evaluation. Examples of such institutions include the guilds and the guards, which safeguarded the political economy of traditional societies.

General beliefs and values involving sacredness of truth, providence, proverbs, idioms, oral histories, oral narratives and altruism are important elements of the political economy of traditional societies. These beliefs and values are usually applied to ensure economic prosperity and political stability. They can still contribute towards peace-building in the contemporary Nigerian society 
even if they are injected into the modern constitution. The Nigerian government and traditional institutions can jointly consider and approve the appointment of mediators for conflict management. Studies on peace agreements have shown the primacy of mediation in the outcome of conflict management (Svensson 2009). It is argued that:

... neutral mediators, who are engaged primarily because of their interest to end the war, will have incentives to hasten the reaching of an agreement to the expense of its quality. By contrast, biased mediators, seeking to protect their protégés, will take care to ensure that there are stipulations in an agreement guaranteeing the interest of 'their' side or use their particular access and leverage to make their side agree to costly concessions. Biased mediation processes are therefore more likely than neutral mediation processes to lead to elaborated institutional arrangements that are generally considered conducive to democracy and durable peace, such as power sharing, third-party security guarantees, and justice provisions (Svensson 2009:446).

Mediation is a critical step in conflict management, and the neutrality of a mediator may be difficult due to the likely influence of a power differential among parties to a conflict. This difficulty can be averted as adoption of some traditional logics of spirituality can contribute towards the success of the process. Rittle (2008) suggested that concerns for spirituality should be a top priority in conflict management strategies, with the belief in the sense of culpability to align human actions with God's will and commands. Rittle's suggestion aligns with African ontological mythology, which remains a central concern for the majority of the population in Africa.

In most African societies, the traditional and the modern systems play complementary roles in ensuring peace and social cohesion. In a number of cases, during the early post-colonial administrations in Africa, traditional rulers formed one of the houses of parliament. Calls have been made for integrating traditional institutions such as the chieftaincy into modern constitution engineering in some cases. The official adoption of traditional measures of 


\section{Akeem Ayofe Akinwale}

conflict management will promote peace and development in Nigeria. The politics of conflict management is expected to connect with the predominant traditions of a society.

\section{Conclusion}

The study is motivated by the rising spate of violent conflicts in Nigeria and the urgent need for adequate measures in managing them. It has focused on modalities for an integration of modern and traditional measures for peacebuilding. The Nigerian government's endeavours at managing violent conflicts have not yielded good results as they largely remain coercive and dismissive of local concerns. Various measures such as police, the military, curfew, propaganda, judicial panel, compensations, creation of new structures, and an offer of amnesty to prevent escalation of violence in Nigeria are replete with lapses, although they have been institutionalised. Similarly, emerging alternative measures such as vigilantes, militias, and ethnic solidarity have resulted in mixed results, whereas the original traditional approaches to conflict management remain grossly repressed. A synergy of different strategies can help in mitigating the rising spate of violence in Nigeria. The coincidence between the establishment of the Ministry for Niger Delta Affairs and the Joint Task Force (JTF)-driven violent raid on militants in the south-south as well as the militants' revocation of the ceasefire constitute a contradiction and lack of integration in the extant conflict management strategies in Nigeria.

A general concern for peace, security, and development remains central in both the traditional and modern strategies for conflict management despite the divergent approaches therein. Limitations of the official conflict management strategies and state failure to recognise and harness useful traditional approaches to social control have made conflicts uncontrollable in Nigeria. It is therefore recommended that the strengths of both the traditional and modern strategies of conflict management are essential and should be integrated to promote peace and development. An innovative policy is needed in this direction. The proposed innovative peace policy would promote fruitful collaboration among stakeholders, transformational leadership and a combination of traditional and modern conflict management strategies to stimulate development in Nigeria. 
The fact that traditional and modern values have coexisted for centuries and would continue to do so provides additional justification for the proposed integration.

Useful aspects of traditional social institutions must be utilised and integrated with the official security apparatus to ensure peace in the conflict-ridden contemporary Nigerian society. The key areas that must be addressed include the issues of land and social justice. These would promote security of lives and properties. The proportion of people that have been using traditional and modern means to eliminate their opponents over land disputes will be drastically reduced. A situation in which governments seize communal land and issue certificates of occupancy to the privileged few at exorbitant costs can undermine peacemaking efforts. Alternatively, governments can liaise with communities concerning the use of their lands for developmental purposes including the construction of infrastructures. If people perceive that the governments meet their needs they would be ready to serve the system and peace will reign. The question of resource control can also be addressed in this regard. Governance with sincerity and transparency will promote security. A genuine integration of modern and traditional conflict management strategies, excluding their pitfalls, would provide lasting solutions to avoidable conflicts in Nigeria. This will result in building democratic institutions of accountability, social inclusion, transparency in governance, and constructive development in Nigeria. Essentially, traditional communication infrastructure and ontological spirituality should be built into the synergised package for conflict management.

\section{Sources}

Abubakar, D. 2006. Identity, citizenship and the crisis of democracy in Nigeria. Paper presented at the annual meeting of the International Studies Association, San Diego, California, 22 March 2006.

Adejumobi, S. 2005. Identity, citizenship and conflict: The African experience. In: Fawole, W.A. and C. Ukeje eds. The crisis of the state and regionalism in West Africa: Identity, citizenship and conflict. Dakar, CODESRIA. pp. 19-41.

Adinoyi, S. 2009. 26 armed mercenaries arrested in Jos. Thisday Newspaper, 1 March 2009. Available from: <www.devilfinder.com $>$ [Accessed 12 June 2009]. 


\section{Akeem Ayofe Akinwale}

Afrobarometer 2002. Violent social conflict and conflict resolution in Nigeria. Briefing Paper No. 2. Available from: <www.afrobarometer.org>' [Accessed 4 July 2009].

Anderson, M. and P. Collins 1998. Introduction. In: Anderson, M. and P. Collins eds. Race, class and gender: An anthology. Belmont, CA, Wadsworth. pp. 1-10.

Balogun, M. 2009. The Jos palaver: time to know the cause, six week after tussle over jurisdiction. News in Africa, 5 (8), pp. 20-21.

Bamgbose, J.A. 2009. Internally displaced persons: Case studies of Nigeria's bomb blast and the Yoruba-Hausa ethnic conflict in Lagos, Nigeria. The Journal of Humanitarian Assistance, 26 May 2009. Available from: <http://jha.ac/2009/05/26/internally-displaced-persons-casestudies $>$ [Accessed 8 July 2009].

Black, D. 1990. The elementary forms of conflict management. New York, Plenum Press.

Borg, M.J. 1992. Conflict management in the modern world-system. Sociological Forum, 7 (2), pp. 261-282.

Cappelen, A. and L. Mjøset 2009. Can Norway be a role model for natural resource abundance countries? Helsinki, UNU-WIDER.

Collier, P. and A. Hoeffler 2005. Resource rents, governance, and conflict source. The Journal of Conflict Resolution, 49 (4), pp. 625-633.

Erinosho, L. 2007. Social values in a reforming society. Keynote address delivered at Nigerian Anthropological and Sociological Association (NASA) National Conference, University of Ibadan, Nigeria, 26 September 2007.

Eya, W. 2009. Jos killings: Much ado about probe panels. Daily Sun, 4 January 2009. Available from: <http://www.sunnewsonline.com> [Accessed 12 June 2009].

Falola, T. 1998. Violence in Nigeria: The crisis of religious politics and secular ideologies. New York, University of Rochester Press.

Fred-Mensah, B.K. 1999. Capturing ambiguities: Communal conflict management alternative in Ghana. World Development, 27 (6), pp. 951-965.

Guseh, J.S. and E. Oritsejafor 2007. Government size, political freedom and economic growth in Nigeria, 1960-2000. Journal of Third World Studies, 24 (1), pp. 139-165.

Hussain, J.S.Z. 2007. Justice at the grassroots level through alternative dispute resolution (ADR) modes. Available from: <http://www.supremecourt.gov.pk/web/subsites/scp50/ Articles/7/7.pdf $>$ [Accessed 8 July 2009].

Ibeanu, O. 2006. Civil society and conflict management in the Niger Delta: Scoping gaps for policy and advocacy. Lagos, CLEEN Foundation.

International Crisis Group. 2009. Nigeria: Seizing the moment in the Niger Delta. Africa policy briefing, 30 April 2009. Abuja/Dakar/Brussels, Author.

Kotlyar, I. and L. Karakowsky 2006. Leading conflict? Linkages between leader behaviors and group conflict. Small Group Research, 37 (4), pp. 377-403. 
Lauer, H. 2007. Depreciating African political culture. Journal of Black Studies, 38 (2), pp. 288-307.

Liu, S. 2006. Towards an analytical theory of social change: The case of China. The British Journal of Sociology, 57 (3), pp. 503-520.

Ma, Z. 2007. Chinese conflict management styles and negotiation behaviours. International Journal of Cross Cultural Management, 7 (1), pp. 101-119.

Meagher, K. 2004. Identity economics: Informal manufacturing and social networks in Southeastern Nigeria. D.Phil. thesis, University of Oxford.

Meagher, K. 2007. Manufacturing disorder: Liberalization, informal enterprise and economic 'ungovernance' in African small firm clusters. Development and Change, 38 (3), pp. 473-503.

Milner, N. 2002. Illusions and delusions about conflict management: In Africa and elsewhere. Law and Social Inquiry, 27 (3), pp. 621-629.

Myerson, R.B. 2009. A field manual for the cradle of civilization: Theory of leadership and lessons of Iraq. Journal of Conflict Resolution, 53 (3), pp. 470-482.

Nwafo Nwanko, R.L and C.G. Nzelibe 1990. Communication and conflict management in African development. Journal of Black Studies, 20 (3), pp. 253-266.

Ochoche, S.A. 2002. Politics and prescriptions for contemporary nation building in Nigeria. A keynote address delivered at the conference of the Institute for Benin Studies, Benin, Nigeria, 17 May 2002.

Osaghae, E.O. 2007. Fragile states. Development in Practice, 17 (4-5), pp. 691-699.

Otite, O. 2000. Ethnic pluralism, ethnicity and ethnic conflict in Nigeria. Second edition. Ibadan, Shaneson C.I. Ltd.

Piiparinen, T. 2007. Putting the cart before the horse: State building, early warning and the irrationality of bureaucratic rationalization. Journal of Intervention and State Building, 1 (3), pp. 355-378.

Rahim, M.A. 1983. A measure of styles of managing interpersonal conflicts. The Academy of Management Journal, 26 (2), pp. 368-376.

Rittle, D.C. 2008. Managing the conflict from within: A spiritual model. Biblical Perspectives. Available from: <http://www.regent.edu/acad/global/publications/bpc_proceedings/2008/ Rittle.pdf $>$ [Accessed 10 July 2009].

Svensson, I. 2009. Who brings which peace? Neutral versus biased mediation and institutional peace arrangements in civil wars. Journal of Conflict Resolution, 53 (3), pp. 446-469.

The US Department of State 2008. Current travel warnings. Available from: <http://travel.state. gov/travel/cis_pa_tw/tw/tw_928.html> [Accessed 10 June 2009].

Thomas K.W. and L.R. Pondy 1977. Toward an 'intent' model of conflict management among principal parties. Human Relations, 30 (12), pp. 1089-1102. 


\section{Akeem Ayofe Akinwale}

Thomas, K.W. 1992. Conflict and negotiation processes in organisations. In: Dunnette, M.D. and L.M. Hough eds. Handbook of industrial and organisational psychology. Palo Alto, CA, Consulting Psychologists Press. pp. 651-717.

USAID 2005. Conflict management and mitigation in Nigeria. Available from: <http://www. devex.com/projects/conflict-management-and-mitigation> [Accessed 16 June 2009].

Volkema, R.J. and T.J. Bergmann 1995. Conflict styles as indicators of behavioural patterns in interpersonal conflicts. The Journal of Social Psychology, 135 (1), pp. 5-15.

Wall, J.A. and R.R. Callister 1995. Conflict and its management. Journal of Management, 21 (3), pp. 515-558. 